\title{
DIAGNOSIS AND THERAPY PARTICULARITIES IN POST- CHOLECYSTECTOMY CHOLANGITIS AT PATIENTS WITH TYPE 2 DIABETES MELLITUS
}

\author{
Mariana Ungur ${ }^{1}$, Alexandra-Lucia Pop ${ }^{2}$, Adrian Maghiar ${ }^{1,},{ }^{3}$ Mircea Pop ${ }^{1,4}$, Bogdan Feder ${ }^{1,4}$ \\ Aurel Petru Babes ${ }^{1,5}$ \\ ${ }^{1}$ University of Oradea, Faculty of Medicine and Pharmacy \\ ${ }^{2}$ Faculty of Economics and Business Administration, Babeș Bolyai University, Cluj Napoca, \\ Romania \\ ${ }^{3}$ Pelican Hospital Oradea \\ ${ }^{4}$ Clinical Emergency County Hospital Oradea, Romania \\ "Maria" Health and Imagery Medical Center, Oradea, Romania \\ Address for correspondence: \\ Dr. Mariana Ungur, assistant professor \\ Department of Surgery, Faculty of Medicine and Pharmacy, University of Oradea \\ 1 Decembrie Street, no. 10, 410068, Oradea, Romania \\ E-mail:marianaungur@gmail.com
}

\begin{abstract}
Introduction. The objective of the present study is to assess the diagnosis and therapeutic particularities in post-cholecystectomy cholangitis at patients with type 2 diabetes mellitus. Patients suffering of diabetes frequently present other pathologies existing before cholecystectomy: cardio-vascular, neurological, renal; these conditions can negatively influence the therapeutic approach of the complex post-cholecystectomy pathology.

Material and method. The study was performed on 76 hospitalized patients. The main diagnosis of these patients was post-cholecystectomy cholangitis. 12 patients had type 2 diabetes mellitus as associated condition. A control batch was selected, 12 non-diabetes patients, having approximately the same age, mainly living in urban areas and having the same main hospitalization diagnosis.
\end{abstract}

Results.The etiology of post-cholecystectomy cholangitis in case of patients suffering of diabetes was represented by chronic pancreatitis (25\%), choledochal lithiasis (33.33\%), acute pancreatitis (8.33\%), cholangiocarcinoma (16.66\%), head pancreas tumor (8.33\%).

Conclusions. As a particularity in the surgical approach in case of patients suffering of diabetes within the assessed group, a strict monitoring should be applied in regards with the metabolic status, especially in case of disbalanced diabetes mellitus with chronic complications. 


\section{INTER}

Keywords: post-cholecystectomy cholangitis pancreatitis, cholangiocarcinoma, choledochal lithiasis.

\section{Rezumat}

Introducere. Obiectivul prezentului studiu îl reprezintă evaluarea particularităților diagnostice și terapeutice ale colangitei post-colecistectomie la pacienții cu diabet zaharat de tip 2. Pacienții diabetici prezintă adesea numeroase comorbidități: cardiovasculare, neurologice, renale; aceste afecțiuni pot influența negativ abordarea terapeutică a patologiei complexe post-colecistectomie.

Material și metodă. Studiul a fost realizat pe 76 de pacienți spitalizați. Principalul diagnostic al acestor pacienți a fost colangita post-colecistectomie. Un număr de 12 pacienți prezentau diabet zaharat de tip 2. A fost selectat un lot de control, format din12 pacienți fără diabet, având aproximativ aceeași vârstă, domiciliați în principal în mediul urban și cu același diagnostic principal de spitalizare.

Rezultate. Factorul etiologic al colangitelor post-colecistectomie în cazul pacienților diabetici a fost reprezentat de pancreatită cronică (25\%), litiază coledociană (33,33\%), pancreatită acută (8,33\%), colangiocarcinom (16,66\%), tumoră de cap de pancreas (8,33\%).

Concluzii. Ca o particularitate a abordării chirurgicale în cazul pacienților diabetici, ar trebui aplicată o monitorizare strictă în ceea ce privește starea metabolică, în special în caz de diabet zaharat dezechilibrat cu complicații cronice.

Cuvinte cheie: pancreatită colangitică post-colecistectomie, colangiocarcinom, litiază coledociană. 


\section{Introduction}

The objective of the present study is to assess the diagnosis and therapeutic particularities in post-cholecystectomy cholangitis in case of patients suffering of type 2 diabetes mellitus.

Diabetes mellitus can be an important risk factor in the prevalence of postcholecystectomy's pathology, being similar with the lithiastic bile pathology present before cholecystectomy. Lithiastic bile pathology, with cholesterolitic calculi, has a higher prevalence in case of patients with metabolic disbalances: hyperinsulinemia, decreased tolerance to glucose, obesity, dyslipidemia $^{(1,2)}$.

Patients with type 2 diabetes mellitus frequently suffer of other pathologies preexistent to cholecystectomy in comparison with non-diabetic patients: cardio-vascular, neurological, renal. This aspect can have a negative impact over the therapeutic approach of post-cholecystectomy's complex pathology.

\section{Material and method}

This study was performed on a batch of 76 patients hospitalized beween 2017 and 2018 in the Surgery I Department of the Emergency County Clinical Hospital of Oradea, their main diagnosis being postcholecystectomy cholangitis. Of these, 12 patients (15.78\%) had type 2 diabetes mellitus as associated condition.

For the purpose of having a head-to-head study, a second control batch of subjects was selected, 12 non-diabetes patients, having approximately the same age, mainly living in urban areas and having the same main hospitalization diagnosis, namely postcholecystectomy cholangitis. The criteria for selecting the patients for the two assessment batches were: gender, age, living area, main diagnosis, other associated conditions, anamnesis data, clinical investigations, radio-imagery and laboratory methods.

As laboratory methods, the following were used: serum glucose, glycosuria, glycated hemoglobin, bile retention samples; direct and total bilirubin; hepatic cytolysis teset ASAT, ALAT, GGT; cellular hypofunction tests, coagulation tests: prothrombin, INR; CBC, reactive $C$ protein, tests for renal performance; creatinine, urea; glomerular filtration rate, serum electrolytes;

For the bio-chemistry tests, the spectophonometric method was used (Architect C4000 analyzer); reactive C protein was assessed through the turbidimetry method (Architect C4000 analyzer); glycated hemoglobin assessed through the enzyme method, from integral blood, with Architect c4000 analyzer; blood count - from integral blood, assessed through the photometric impedance method (Cell Dyn Ruby); erythrocyte sedimentation rate (VSH) - from integral blood, assessed through the capilar photometry method, with ALIFAX analyzer.

From the perspective of statistic analysis methodology, the information was processed in the SPSS 17.0 static program; descriptive analysis, Anova and Chi-Square statistic tests were used; the reliability threshold is $95 \%$, meaning that there is a maximum $5 \%$ statistical error; $\mathrm{P}$ or $\mathrm{P}$-value is seen as probability or Pearson value.

As treatment methods, pharmacology, interventional imagery (retrograde endoscopic cholangiopancreatography) and, with decreased frequency, surgery (invasive on bile ducts and mini-invasive) were used. In case of patients suffering of diabetes who 


\section{INTERNAL}

\section{Original papers}

undergone surgery treatment methods, specific pre, intra and post-surgery specific measures were applied. These were used for the purpose of avoiding hypo-glycemic acute disbalances and also intra and post-surgery ketoacidosis and hyperglycemia disbalances. Post-surgery, high values of glycemia increase the risk of thrombotic accidents, prevent quick post-surgery recovery and favor the development of septic complications.

\section{Results}

From the total number of patients hospitalized with post-cholecystectomy cholangitis during 2017-2018, women had a percentage of $66.66 \%$. Within the batch of patients with diabetes, $83.83 \%$ were living in urban areas. The patients belonged to the age group of over 65 years of age, the percentage being $91.66 \%$. Within the 12 patients suffering of type 2 diabetes mellitus between 2017-2018 diagnosed with postcholecystectomy cholangitis, 7 patients had type 2 diabetes mellitus with need for insulin. Out if these 6 cases, 3 were cases of type 2 dibetes mellitus with disbalanced need for insulin.

Other frequent associated pathologies within batch I of study were connected to diabetes complications: cardio-vascular (congestive heart failure, chronic arterial fibrillation, high blood pressure, chronic coronary heart disease), renal (acute and chronic kidney failure), neurological (stroke) and opthalmologic (cecity). Other co-morbidities in the assessed batch were: hepatic steatosis, chronic hepatopathy, obesity.

At hospitalization, in case of patients suffering of diabetes, in 9 cases $(75.00 \%)$ high glycemic values were present (150-406 $\mathrm{mg} / \mathrm{dl}$ ); in case of a patient with disbalanced insulin needing diabetes, hypoglycemia was present (38mg/dl).

The presence of a significantly statistic difference has been identified $(p=0.017)$, at a reliability threshold of $95 \%$, between the average of blood sugar in case of patients suffering of diabetes ( $183.40 \mathrm{mg} / \mathrm{dl}$ ) and the average of blood sugar in case of patients not suffering of diabetes ( $108 \mathrm{mg} / \mathrm{dl})$, thus in the case of patients diagnosed with diabetes, the blood sugar values highly outrun the normal values.

In case of two patients hospitalized with postcholecystectomy cholangitis and type 2 disbalanced diabetes mellitus, severe hydroelectrolytic disbalances were present.

Bile-excretive syndrome associated with inflammation had a high percentage (58.33\%). Cholestasis and hepatocytolysis syndrome had a significant percentage (66.66\%).

There were high values of gamma glutamyl transferase with high specificity and 


\begin{tabular}{|c|c|c|}
\hline Chronic pancreatitis & 3 & $25.00 \%$ \\
\hline Acute pancreatitis & 1 & $8.33 \%$ \\
\hline Pancreatic cephalic tumor & 1 & $8.33 \%$ \\
\hline Choledochal lithiasis & 4 & $33.33 \%$ \\
\hline Inferir choledocial cholangio-carcinoma & 2 & $16.66 \%$ \\
\hline Klatskin tumor & 1 & $8.33 \%$ \\
\hline
\end{tabular}

Table 1. Etiology of post-cholecystectomy cholangitis hospitalized patients with diabetes

\begin{tabular}{|c|c|c|c|}
\hline \multicolumn{2}{|c|}{$\begin{array}{c}\text { Number of diabetes patients with post-cholecystectomy cholangitis } \\
\text { (study batch) }\end{array}$} & 12 & $100 \%$ \\
\hline \multirow{2}{*}{$\begin{array}{c}\text { Endoscopic methods } \\
\text { (ERCP) }\end{array}$} & Endoscopic sphincterectomy with extraction of \\
residual calculi & 3 & $25.00 \%$ \\
\cline { 2 - 4 } & Suppression of the stent placed on the main bile & 1 & $8.33 \%$ \\
\hline \multirow{2}{*}{$\begin{array}{c}\text { Invasive } \\
\text { surgery methods }\end{array}$} & Choledochotomy + external bile drainage & 1 & $8.33 \%$ \\
\cline { 2 - 4 } & Explohration laparotomy & 1 & $8.33 \%$ \\
\hline
\end{tabular}

Table 2. Prevalence of therapeutic approach methods in case of diabetes patients with postcholecystectomy cholangitis

\begin{tabular}{|c|c|c|}
\hline Residual choledochal lithiasis & 6 & $33.33 \%$ \\
\hline Stenosis of choledochal-duodenum anastomosis & 1 & $8.33 \%$ \\
\hline Stenosis of distal choledoch & 1 & $8.33 \%$ \\
\hline Acute pancreatitis & 1 & $25.00 \%$ \\
\hline Chronic pancreatitis & 3 & $16.66 \%$ \\
\hline
\end{tabular}

Table 3. Etiology of post-cholecystectomy cholangitis in case on non-diabetes patiets (control batch) 


\section{INTEH}

Number of non-diabetes patients with post-cholecystectomy cholangitis (control batch)

Pharmacological methods

Endoscopic retrograde cholangiopancreatography-endoscopic sphincterectomy with extraction of residual calculi

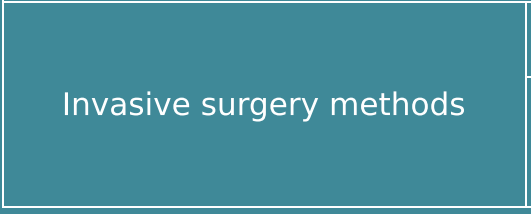

Choledochotomy + choledoc-duodenum anastomosis

Table 4. Prevalence of therapeutic approach methods in case of non-diabetes patients with postcholecystectomy cholangitis

sensibility in the diagnosis of postcholecystectomy main bile duct residual lithiasis.

Within the assessment batch, of patients suffering of diabetes, there is a significantly positive statistics and directly proportional connection at a reliability threshold of $95 \%$ between the etiology of postcholecystectomy cholangitis and GGT type hepatic cytolysis syndrome $(p=0.027)$, thus: the higher the value of gamma glutamil transferasis (GGT) is, the more severe the condition is, a low value of GGT variable is seen in acute pacreatitis, while a higher value of GGT variable lead to diagnosing the patient with a tumoral pathology. Within the control batch, there is a significantly positive statistics and directly proportional connection at a reliability threshold of $95 \%$ between the etiology of postcholecystectomy cholangitis and ALAT type hepatic cytolysis syndrome $(p=0.014)$, thus a lower value of ALAT variable leads to lighter diagnosis (pancreatitis), and a higher value of the ALAT variable leads to a more severe diagnosis (benign or malign stenosis).

Surgery was performed in one case, a patient with type 2 diabetes mellitus without insulin need, associated with an acute postcholecystectomy cholangitis of malign etiology (main bile duct tumor, without the ability to perform surgery). The patient had a mechanic icterus, with marked bileexcretory syndrome (direct bilirubin - 
$18,63 \mathrm{mg} / \mathrm{dl}$; total bilirubin $25,33 \mathrm{mg} / \mathrm{dl}$ ), intrahepatic cholestasis and hepatic failure, with increased hepatocytolysis syndrome (very high values of gamma glutamyl transferase $-2528 \mathrm{U} / \mathrm{L}$ ). Also, the patient was suffering of associated chronic pancreatitis. Also, glycemic values were high at hospitalization - $269 \mathrm{mg} / \mathrm{dl}$. As palliative surgery treatment, choledochotomy with external Kehr tube drainage was performed.

The second case where surgery was performed was the case of a female patient with diabetes mellitus with balanced need for insulin, hospitalized with postcholecystectomy cholangitis through pancreatic cephalic tumor, with dudenum invasion; in her surgery medical history she had several interventions for bile obstructive pathology (cholecystectomy, anastomosischoledochal-duodenum).

Exploration laparotomy was performed, without the possibility of tumoral excision due to adherence to the portal vein. Glycemia had values of $169 \mathrm{mg} / \mathrm{dl}$. There is a significant positive statistics correlation at a reliability threshold of $95 \%$ between the etiology of post-cholecystectomy cholangitis in case of patients with diabetes and the therapeutic approach ( $p=0.049$ ), thus, in acute cholangitis severe cases will be approached as precociously as possible for draining the bile ducts, with endoscopic or surgery methods; light or moderate chronic or acute cholangitis cases respond efficiently to specific anti-microbe therapy.

Of high importance in these surgery cases was the pre-surgery, intra-surgery and postsurgery monitoring of patients suffering of diabetes.

We have to take into account the negative impact of a surgical intervention in situations of blood sugar level disturbance. In 6 cases, the treatment of post-cholecystectomy cholangitis has been performed with pharmacology methods similar to those used in case of patients without diabetes. In 3 cases, endoscopic sphincterectomy through retrograde e n d o s c o p i c cholangiopancreatography has been performed, with extraction of calculi through choledocal lithiasis in case of patients with post-cholecystectomy cholangitis.

In one case it was necessary to endoscopically suppress a choledocal stent, in a specialized center, a postcholecystectomy cholangitis patient with type 2 diabetes mellitus with need for insulin. The patient has shown post ERCP angiocholitis after placing a stent on the main bile duct for an inferior choledocal cholangio-carcinoma. At hospitalization, the patient had high blood sugar values $(406 \mathrm{mg} / \mathrm{dl})$, an inflammatory, marked bileexcretory and hepatocytolitic syndrome.

In 6 cases, the treatment of postcholecystectomy angiocholitis has been performed with pharmacology methods similar to those used in case of patients without diabetes. As a control batch, in the reference study, 12 non-diabetes patients were assessed who were hospitalized with post-cholecystectomy cholangitis

There is a significant statistics correlation at a reliability threshold of $95 \%$ between the etiology of post-cholecystectomy cholangitis and the terapeuthic approach, namely that in choledochal lithiasis endoscopic sphincterotomy will be applied, with extraction of residual choledochal calculi, in case of acute and chronic disorders pharmaceutical methods will be used, in a limited number of cases surgery management will be chosen.

As pathologies in the control batch, other possible causes associated to the pathology of post-cholecystectomy were observed: 


\section{INTERNAL}

\section{Original papers}

duodenum-gastric bile reflux, corporeal edematous gastropathy, satellite hepatitis. Other pathologies were also reported, especially cardio-vascular pathology.

\section{Discussions}

Type 2 diabetes mellitus has an important role in the lithogenesis process; an over saturation of the bile with cholesterol is generated, especially in case of obese patients and with dyslipidemia and in case of patients with type 2 diabetes mellitus with insulin need, after the initiation of insulin therapy. The low level of HDL cholesterol will generate an increase of cholesterol hepatic secretion and a decrease of the concentration of bile salts and phospholipids. There will be an over-saturation of the bile, with the precipitation of cholesterol crystals and, over time, the development of cholesterol calculi $^{(1,2,3)}$. The mechanism of this cholesterol lithogenesis is closely connected with type 2 diabetes mellitus, with obesity, dyslipidemia and hyper-hyperinsulinemia. As additional factors, the inflammation of the bile ducts and low intestine mobility were reported. Recent specialty studies highlight the role of nuclear receptors, of damaged intestinal flora and of genetic polymorphism $^{(2,3,4)}$.

The patient with type 2 diabetes mellitus has a higher morbidity than the non-diabetic patient in the incidence of postcholecystectomy. The prevalence of females in the assessed batch of patients was higher than the prevalence of males, similar to the higher prevalence of females in the pathology of lithiastic bile pathology ${ }^{(5,6,7)}$. Patients with type 2 diabetes from urban areas were higher in number. Type 2 diabetes mellitus was higher in case of patients with age over 65, who were hospitalized with post-cholecystectomy pathology. In case of these patients, rigorous monitoring was needed for avoiding long term diabetes complications, for avoiding hypoglycemia and maintaining a suitable life quality standard.

In the study batch with diabetes patients, the most frequent causes of postcholecystectomy cholangitis were chronic pancreatitis, choledochal lithiasis and malign pathology (cholangiocarcinoma, Klaszkin tumor, pancreatic cephalic tumor).

Pancreatic and peripancreatic chronic inflammatory processes can determine exocrine and endocrine pancreatic insufficiency with hyperglycemia and type 2 diabetes mellitus (pancreatogenic diabetes) $)^{(8,9,10,11,12)}$. Pathologic situation with subsequent impact over the pancreas are: acute, chronic pancreatitis, malign pancreatic tumors, traumas, atherosclerosis. Chronic cephalic pancreatitis is usually accompanying choledochal lithiasis, being 
the consequence of infection spread through means of canals and contiguity.

Also, the long-term evolution of a type 2 diabetes mellitus determines important pancreas changes which will be added to the post-cholecystectomy pancreatic changes. There are controversies in the specialty literature, in regards with type 2 diabetes mellitus favoring or not the development of chronic pancreatitis and of postcholecystectomy pancreatic tumoral pathology ${ }^{(13)}$. This risk would be lower in case of patients with type 2 diabetes mellitus, non-insulin dependent, due to the administration of metformin, in comparison with the higher risk of developing pancreas cancer in case of patients with type 2 diabetes mellitus who need insulin ${ }^{(14,15)}$.

Also, it is not clear if diabetes mellitus is the cause or the effect of pancreatic cancer. Specialty studies show that, generally, in case of patients with malign pancreatic tumor, diabetes mellitus has been recently diagnosed, being the consequence of the destruction of the pancreas by the invasion of malign cells $\mathrm{s}^{(14,15)}$.

A type 2 diabetes mellitus which has a longterm evolution (5-7 years) can represent a risk factor for developing a pancreatic tumor. To this we can also add as an increased risk potential the effects of anti-diabetes medication. When the diagnosis was established before the pancreas cancer diagnosis, diabetes mellitus was non-insulin dependent. The association between postcholecystectomy pancreatic malign tumor and diabetes mellitus can be present, the prognosis being unfavorable. The information from different specialty studies are contradictory, more in-depth studies being needed for an exact understanding of the connection between chronic pancreatitis, pancreas cancer and type 2 diabetes mellitus $^{(13,14,15)}$. Also, there were patients with type 2 diabetes mellitus within the study batch hospitalized with postcholecystectomy choledochal lithiasis.

Specialty studies confirm the association between diabetes and residual lithiasis of bile ducts. The low level of high-density lipoproteins (HDL) is an important mediator of the effects of type 2 diabetes mellitus over the post-cholecystectomy residual bile calculi.

There is a possible connection between type 2 diabetes mellitus and cholangiocarcinoma in case of patients with intervention in the bile area. Recent specialty studies assess the potential risk of certain additional factors in the pathogenesis of cholangiocarcinoma: $\mathrm{B}$ or $C$ hepatitis, type 2 diabetes mellitus, obesity, alcoholic hepatopathy, hepathic cirrhosis, smoking. Post-cholecystectomy, increased bile secretion can favor the process of carcinogenesis on the level of the bile ducts through a mechanism similar to the carcinogenetic process on the hepatocitary level ${ }^{(16,17,18,19)}$.

The results gathered in the study batch with patients with type 2 diabetes mellitus, hospitalized with post-cholecystectomy angiocholitis and who were also diagnosed with chlangiocarcinoma are similar with the ones shown by recent specialty studies.

The therapeutic attitude in postcholecystectomy cholangitis in case of patients with diabetes has been mainly based on specific medication methods, interventional imagery methods and, in only on a very low number of cases, on invasive surgery methods.

The increased susceptibility of diabetes patients to infections, high glycemic serum levels, hyperinsulinemia, malnutrition, dehidration, association of different cardiovascular comorbidities can negatively 


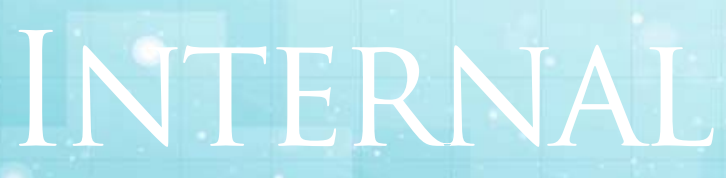

Original papers

influence the post-surgery evolution. In case of diabetes patients, there is a deficient immune response to the inflammatory process, an inefficient chemotactic neutrophilic phagocytosis activity and also an incorrect intracellular bacteria activity $^{(20,21)}$.

Surgical intervention and anesthesia have an important impact over the metabolic balance of the body. The diabetes patient has a higher risk than the non-diabetes patient to show metabolic and hydro-electrolytic intra and post-surgery disbalances.

Complex therapeutic approach aims at avoiding acute hypoglycemia disbalances during the anesthesia, ceto-acidosis and hyperglycemia during the intra and postsurgery period.

Post-surgery, the increased serum values on glycemia increase the risk of thrombotic accidents, obstruct the surgical healing of wounds and foster the development of abdominal parietal abscesses. (30) The surgical activity involves a period of starvation and a hypersecretion of counterregulating hormones as a metabolic response to the stress created by the surgery. Thus, the high levels of cortisol, catecholamines and glucagon will have a counter effect over the insulin ${ }^{(22,23)}$.

Disbalanced diabetes mellitus and diabetic cardio-vascular, renal or neurological complications create a potential risk within the surgical approach of the postcholecystectomy bile pathology, similar to general surgery approach.

As a first pre-surgery measure in case of a patient with diabetes, a complete reassessment is performed by an interdisciplinary team (surgeon, diabetologist, cardiologist, nephrologist, anesthesiologist). The purpose is to assure a glycemia control and correcting hydro-electrolitic and metabolic disbalances in case of patients who also have multiple comorbidities and specific diabetes complications, especially cardio-vascular and renal $^{(24,25)}$.

Another measure, before a major surgery intervention with general anesthesia, is replacing the oral anti-diabetes medication with the according insulin treatment. If there are metabolic and/or hydro-electrolitic disbalances, the surgical intervention will be postponed until these are corrected. Intrasurgery, $500 \mathrm{ml}$ of glucoses $10 \%+25$ u.i. insulin with quick effect will be administered. The optimum glycemic level was maintained in accordance with the international therapeutic protocols, keeping glycemic values between $125-200 \mathrm{ml} / \mathrm{dl}^{(26,27)}$.

Post-surgery, IV treatment was continued in accordance with the scheme presented by the diabetologist and anesthesiologist. Using IV treatment with glucose solution buffered with insulin has led to a constant monitoring of the blood sugar at intervals of $2 \mathrm{~h}$. 
Based on the hydro-electrolitic and metabolic status of the diabetic patient, the diabetologist has established the optimum timing for administering under-cutaneous quick insulin. The surgical prognostic of the diabetes patients from the study group was favorable. This aspect allowed returning to the previous hypo-glycemic treatment schemes.

\section{Conclusions}

In both batches, both in the diabetic patients batch, and in the control batch on nondiabetic patients, post-cholecystectomy residual choledochal lithiasis was the main etiology.

In both batches - diabetes patients versus non-diabetic patients - the therapeutic approach in similar: pharmaceutical methods, interventional imagery and invasive surgery.

As a particularity in the surgical approach in case of patients suffering of diabetes within the assessed group, a correct and careful monitoring should be applied in regards with the metabolic status, especially in case of disbalanced diabetes mellitus with chronic complications.

\section{Bibliography}

1. Di Ciaula A, Wang DQ, Portincasa P. Cholesterol cholelithiasis: part of a systemic metabolic disease, prone to primary prevention. Expert Rev Gastroenterol Hepatol. 2019 Feb;13(2):157-171

2. Di Ciaula A, Molina-Molina E, Bonfrate L, Wang DQ, Dumitrascu DL, Portincasa P. Gastrointestinal defects in gallstone and cholecystectomized patients. Eur J Clin Invest. 2019 Mar; 49(3):e13066

3. Di Ciaula A, Garruti G, Wang DQ, Portincasa P. Cholecystectomy and risk of metabolic syndrome. Eur J Intern Med. 2018 Jul; 53:3-11

4. Halldestam I, Enell EL, Kullman E, Borch K. Development of symptoms and complications in individuals with asymptomatic gallstones. BrJSurg. 2004 Jun;91(6):734-8

5. Kautzky-Willer A, Harreiter J, Pacini G. Sex and gender differences in risk, pathophysiology and complications of type
2 diabetes mellitus. EndocrRev. 2016 Jun;37(3):278-316

6. van Zon SK, Snieder H, Bültmann U, Reijneveld SA. The interaction of socioeconomic position and type 2 diabetes mellitus family history: a cross-sectional analysis of the Lifelines Cohort and Biobank Study. BMJ Open. 2017 Apr 7;7(4):e015275.

7. Ali S, Ahamad ST, Talpur AS, Parajuli S, Farooq J. Prevalence of Non-insulin-dependent Diabetes Mellitus Among Patients with Cholelithiasis: A Single-centered, Cross-sectional Study. Cureus. 2018 Apr 7;10(4):e2444.

8. Zechner D, Radecke T, Amme J, Bürtin F, Albert AC, Partecke LI, Vollmar B. Impact of diabetes type II and chronic inflammation on pancreatic cancer. BMC Cancer. 2015 Feb 13;15:51.

9. Hart PA, Bellin MD, Andersen DK, Bradley D, CruzMonserrate Z, Forsmark CE, Goodarzi MO, Habtezion A, Korc M, Kudva YC, Pandol SJ. Type 3c (pancreatogenic) diabetes mellitus secondary to chronic pancreatitis and pancreatic cancer. Lancet Gastroenterol Hepatol. 2016 Nov; 1(3):226-237 10. Ramsey ML, Conwell DL, Hart PA. Complications of chronic pancreatitis. Dig Dis Sci. 2017 Jul;62(7):1745-1750

11. Löhr JM, Dominguez-Munoz E, Rosendahl J, Besselink M, Mayerle J, Lerch MM, Haas S, Akisik F, Kartalis N, Iglesias-Garcia J, Keller J. United European Gastroenterology evidence-based guidelines for the diagnosis and therapy of chronic pancreatitis (HaPanEU). United European Gastroenterol J. 2017 Mar;5(2):153-199

12. Bellin MD, Whitcomb DC, AbberbockJ, Sherman S, Sandhu BS, Gardner TB, Anderson MA, Lewis MD, Alkaade S, Singh VK, Baillie J. Patient and disease characteristics associated with the presence of diabetes mellitus in adults with chronic pancreatitis in the United States. Am J Gastroenterol. 2017 Sep;112(9):1457-1465

13. Andersen DK, Korc M, Petersen GM, Eibl G, Li D, Rickels MR, Chari ST, Abbruzzese JL. Diabetes, pancreatogenic diabetes, and pancreatic cancer. Diabetes. 2017 May;66(5):1103-1110.

14. Siegel RL, Miller KD, Jemal A. Cancer statistics, 2016. CA CancerJClin. 2016Jan-Feb;66(1):7-30

15. Moses $A C$, Knudsen $L B$, Svendsen $C B$. Comment on Andersen et al, pancreatitis-diabetes-pancreatic cancer: summary of an NIDDK-NCI workshop. Pancreas.2014 May;43(4):657

16. Xiong J, Wang $Y$, Huang $H$, Bian J, Wang A, Long J, Zheng $Y$, Sang $X, X U Y, L U X$, Zhao $H$. Systematic review and metaanalysis: cholecystectomy and the risk of cholangiocarcinoma. Oncotarget. 2017Jul 26;8(35):59648-59657

17. Shafqet $M$, Sharzehi K. Diabetes and the pancreatobiliary diseases. Curr Treat Options Gastroenterol. 2017 Dec;15(4):508-519

18. Huang YJ, Wu AT, Chiou HY, Chuang MT, Meng TC, Chien LN, Yen $Y$. Interactive role of diabetes mellitus and female sex in the risk of cholangiocarcinoma: a population-based nested casecontrol study. Oncotarget. 2017 Jan 24;8(4):6642-6651 19. Bragazzi MC, Ridola L, Safarikia S, Di Matteo S, Costantini D, 


\section{INTERNAI Original papers}

Nevi L, Cardinale V. New insights into cholangiocarcinoma: multiple stems and related cell lineages of origin. Ann Gastroenterol. 2018Jan-Feb;31(1):42-55

20. Toniolo A, Cassani G, Puggioni A, Rossi A, Colombo A, Onodera $T$, Ferrannini $E$. The diabetes pandemic and associated infections: suggestions for clinical microbiology. Rev Med Microbiol. 2019Jan;30(1):1-17

21. Koh GC, Peacock SJ, Van der Poll T, Wiersinga WJ. The impact of diabetes on the pathogenesis of sepsis. Eur J Clin Microbiol InfectDis. 2012 Apr;31(4):379-88

22. Cosson $E$, Catargi $B$, Cheisson $G$, Jacqueminet $S$, Ichai $C$, Leguerrier AM, Ouattara A, Tauveron I, Bismuth E, Benhamou $D$, Valensi P. Practical management of diabetes patients before, during and after surgery: A joint French diabetology and anaesthesiology position statement. Diabetes Metab. 2018Jun;44(3):200-216

23. Cheisson $G$, Jacqueminet $S$, Cosson $E$, Ichai $C$, Leguerrier $A M$, Nicolescu-Catargi B, Ouattara A, Tauveron I, Valensi $P$,
Benhamou D. Perioperative management of adult diabetic patients. Intraoperative period. Anaesth Crit Care Pain Med. 2018Jun;37 Suppl 1:S21-S25.

24. Thompson BM, Stearns JD, Apsey HA, Schlinkert RT, Cook $C B$. Perioperative management of patients with diabetes and hyperglycemia undergoing elective surgery. Curr Diab Rep. 2016Jan;16(1):2..

25. Thompson BM, Stearns JD, Apsey HA, Schlinkert RT, Cook $C B$. Perioperative management of patients with diabetes and hyperglycemia undergoing elective surgery. Curr Diab Rep. 2016Jan;16(1):2.

26. Evans CH, Lee J, Ruhlman MK. Optimal glucose management in the perioperative period. Surg Clin North Am. 2015 Apr;95(2):337-54 Surgical Clinics. 2015 Apr 1;95(2):33754.

27. American Diabetes Association. 14. Diabetes Care in the Hospital: Standards of Medical Care in Diabetes- 2018. Diabetes Care. 2018 Jan;41(Suppl 1):S144-S151. 